\title{
Sumbangan Pemikiran Hak Asasi Manusia Terhadap Pembaharuan Kitab Undang- Undang Hukum Acara Pidana (KUHAP)
}

\author{
Ari Wibowo
}

DATA NASKAH

Masuk: 19 Februari 2016

Diterima: 23 Juni 2016

Terbit: 8 Desember 2016

KORESPONDEN PENULIS:

Fakultas Hukum Universitas Islam Indonesia, Jalan Taman Siswa No. 158, Mergangsan, Yogyakarta, Daerah Istimewa Yogyakarta

Email: a.wibowo@uii.ac.id

\section{ABSTRACT}

The idea of renewal of the Criminal Procedure Code can not be separated from the contributions of human rights concept. These contributions have been explicitly included in the preamble of the Draft of Criminal Procedure Code. This article comprehensively analyzes what are the contributions of human rights concept to the renewal of Criminal Procedure Code regarding the protection of defendant and victim of crime? The result of the study finds that although the Criminal Procedure Code already provides protection to the rights of the defendant, but it is still not optimal. Therefore, in the Draft of Criminal Procedure Code there is a new institution called the Rechter-Commissaris to replace the Pretrial Institutions. It has far wider powers of Pretrial Institution, so that the protection of defendant rights will be more secure fulfillment. The development of human rights concept also contributed to the idea to regulate the rights of victim.

Key words: contribution, human rights, renewal of Criminal Procedure Code

\section{ABSTRAK}

Gagasan pembaharuan Kitab Undang-Undang Hukum Acara Pidana (KUHP) tidak dapat dilepaskan dari sumbangan pemikiran Hak Asasi Manusia (HAM). Sumbangan ini secara eksplisit disebutkan dalam konsiderans Rancangan Kitab Undang-Undang Hukum Pidana (KUHAP). Permasalahan yang diangkat dalam tulisan ini adalah apa kontribusi konsep Hak Asasi Manusia (HAM) terhadap pembaharuan Kitab Undang-Undang Hukum Pidana (KUHAP) baik menyangkut perlindungan terhadap hak-hak tersangka atau terdakwa maupun korban tindak pidana? Dari hasil kajian yang dilakukan menunjukkan bahwa meskipun Kitab Undang-Undang Hukum Pidana (KUHAP) telah mengatur perlindungan terhadap hak-hak tersangka atau terdakwa, akan tetapi masih belum maksimal. Untuk lebih memaksimalkan 
perlindungan tersebut, dalam Rancangan Kitab Undang-Undang Hukum Pidana (KUHAP) terdapat institusi baru yang disebut sebagai hakim komisaris untuk menggantikan praperadilan dengan fungsi yang lebih luas sehingga lebih menjamin perlindungan hakhak tersangka atau terdakwa. Selain itu, perkembangan pemikiran Hak Asasi Manusia (HAM) juga memberikan sumbangan terhadap gagasan mengenai pengaturan perlindungan terhadap korban yang lebih memadai.

Kata kunci: sumbangan, Hak Asasi Manusia, pembaharuan Kitab Undang-undang Hukum Acara Pidana

\section{PENDAHULUAN}

Menurut Hobbes, manusia pada dasarnya memiliki watak agresif, yaitu naluri untuk menyerang, menguasai harta orang lain atau memiliki ambisi untuk berkuasa. Karena watak itulah sehingga manusia bisa menjadi serigala bagi orang lain (homo homini lupus) (Suhelmi, 2001: 247). Bertolak dari pandangan Hobbes tersebut, maka keberadaan kejahatan merupakan suatu keniscayaan dalam kehidupan bermasyarakat. Kejahatan tidak mungkin dihilangkan, namun hanya dapat dikurangi kuantitas dan kualitasnya. Pernyataan tersebut secara empiris juga dapat dibuktikan bahwa sejak manusia dilahirkan hingga saat ini kejahatan terus ada bahkan semakin kompleks.

Karena adanya kecenderungan dari setiap orang untuk melakukan kejahatan, maka dibutuhkan institusi yang dapat mengatur kehidupan bermasyarakat agar hak-hak setiap manusia dapat terlindungi. Atas dasar inilah John Locke mengemukakan teori yang dikenal sebagai social contract theory (teori kontrak sosial). Menurut teori ini, Negara dibangun atas dasar kontrak sosial antara pemerintah sebagai pemegang kekuasaan dengan rakyat sebagai pemegang kedaulatan. Pemerintah diberikan kekuasaan untuk menyelenggarakan ketertiban dan menciptakan suasana dimana rakyat dapat menikmati hak-hak alamnya (natural right) dengan aman. Di lain pihak rakyat akan mematuhi pemerintah apabila hak-hak tersebut terjamin (Budiardjo, 2008: 111).

Atas dasar kontrak sosial tersebut, pemerintah diberikan kekuasaan untuk menentukan kebijakan-kebijakan guna menciptakan ketertiban masyarakat, salah satunya melalui kebijakan hukum pidana (penal policy) (Najih, 2008: 29).
Menurut A. Mulder, kebijakan hukum pidana merupakan garis kebijakan untuk menentukan seberapa jauh ketentuanketentuan pidana yang berlaku perlu diubah atau diperbaharui, apa yang dapat diperbuat untuk mencegah terjadinya tindak pidana, dan cara bagaimana penyidikan, penuntutan, peradilan dan pelaksanaan pidana harus dilaksanakan (Arief, 2003: 26). Ruang lingkup dari kebijakan hukum pidana dapat meliputi kebijakan formulatif, aplikatif, dan eksekutif (Amrullah, 2007: 21).

Pada tahapan formulatif, kebijakan hukum pidana menghasilkan undang-undang hukum pidana yang meliputi tiga bentuk, yaitu hukum pidana materiel, hukum pidana formil (hukum acara pidana), dan hukum pidana eksekutoriel. Dari ketiga undang-undang pidana tersebut, salah satunya adalah hukum pidana formil berupa norma-norma yang mengatur kapan dan dalam hal apa kepada mereka yang melanggar larangan-larangan itu dapat dikenakan atau dijatuhi pidana sebagaimana yang telah diancamkan. Hukum pidana eksekutoriel sendiri merupakan norma-norma dengan cara bagaimana pengenaan pidana itu dapat dilaksanakan apabila ada orang yang diputus telah melanggar larangan tersebut (Moeljatno, 2008: 1).

Saat ini, undang-undang induk hukum pidana formil di Indonesia adalah Kitab Undang-Undang Hukum Acara Pidana yang untuk selanjutmya dalam tulisan ini disebut dengan KUHAP. Karena usianya sudah tua, maka dipandang perlu untuk dilakukan pembaharuan terhadap undangundang kodifikasi tersebut. Pembaharuan terhadap KUHAP sudah merupakan kebutuhan mendesak. KUHAP sendiri diatur melalui Undang-Undang Nomor: 8 Tahun 1981, tentang Kitab Undang-Undang Hukum Acara Pidana, yang berlaku mulai tanggal 31 Desember 1981. KUHAP merupakan hukum acara pidana yang menggantikan Herziene Inlandsch Reglement (HIR) warisan kolonial Belanda yang ketika itu dianggap tidak sesuai lagi dengan karakteristik negara merdeka. Berbeda dengan HIR, KUHAP memperlihatkan ciri yang lebih humanis, tidak lagi menggunakan cara-cara kekerasan (violence) atau penyiksaan (torture) oleh aparat penegak hukum dalam proses penegakan hukum pidana (Anwar dan Adang, 2008, 45). Seiring dengan berjalannya waktu, kemudian muncul ide untuk melakukan pembaharuan terhadap KUHAP dan saat ini telah terbentuk 


\section{MEDIA
HUKUM}

Rancangan KUHAP. Salah satu faktor yang mempengaruhi ide pembaharuan KUHAP adalah perkembangan pemikiran Hak Asasi Manusia Pidana yang untuk selanjutmya dalam tulisan ini disebut dengan HAM. Oleh karena itu, permasalahan yang dikaji dalam artikel ini adalah apa sumbangan konsep HAM dalam pembaharuan KUHAP terkait dengan perlindungan terhadap hak-hak tersangka atau terdakwa dan korban tindak pidana?

\section{PEMBAHASAN}

\section{A. Konsep Pembaharuan Hukum Pidana}

Pembaharuan hukum pidana dapat dimaknai sebagai perubahan terhadap hukum pidana. Pembaharuan hukum pidana dilakukan secara sistemik, yaitu dengan pendekatan yang integral dan menyeluruh. Perlu menjadi catatan, bahwa pendekatan sistemik tidak mengharuskan perubahan hukum pidana secara total, namun tetap mempertahankan yang masih dianggap baik, mengganti yang dianggap tidak sesuai dan menambah yang dianggap kurang (Prasetyo, 2010: 30). Pembaharuan hukum pidana hendaknya tidak hanya dilakukan oleh orang yang duduk di pemerintahan, namun dibutuhkan juga peran dari akademisi. Para pakar hukum pidana harus merasa dirinya sebagai bagian dari sistem hukum pidana, tidak terbatas sebagai pengamat, namun sebagai kontributor dalam pembuatan dan penerapan hukum pidana (Dubber, 1999).

Objek pembaharuan hukum pidana tidak hanya secara mikro, yaitu hukum pidana materiil, namun objek pembaharuan hukum pidana juga secara makro yang meliputi pembaharuan pada struktur atau lembaga-lembaga sistem peradilan pidana, substansinya yang menyangkut harmonisasi atau sinkronisasi hukum pidana, serta pembaharuan aspek budaya masyarakat, dan nilai-nilai filosofis kehidupan (Prasetyo, 2010: 31). Dengan demikian, pembaharuan hukum pidana tidak sekedar melakukan pembaharuan pada hukum pidana materiel, namun juga secara makro dilakukan terhadap ruang lingkup yang lebih luas termasuk hukum pidana formil, bahkan lebih dari itu hingga menyentuh kebijakan kriminal dan kebijakan sosial.

Menurut Barda Nawawi Arief (2008: 26), makna dan hakekat pembaharuan hukum pidana meliputi:

1. Dilihat dari sudut pendekatan kebijakan, yaitu: a. Sebagai bagian dari kebijakan sosial (social policy), pembaharuan hukum pidana pada hakekatnya merupakan bagian dari upaya untuk mengatasi masalahmasalah sosial (termasuk masalah kemanusiaan) dalam rangka mencapai tujuan nasional.

b. Sebagai bagian dari kebijakan (criminal policy), pembaharuan hukum pidana pada hakekatnya merupakan bagian dari upaya perlindungan masyarakat (social defence), khususnya penanggulangan kejahatan.

c. Sebagai bagian dari kebijakan penegakan hukum (law enforcement policy), pembaharuan hukum pidana pada hakekatnya merupakan bagian dari upaya memperbaharui substansi hukum (legal substance) dalam rangka lebih mengefektifkan penegakan hukum.

2. Dilihat dari sudut pendekatan nilai, pembaharuan hukum pidana pada hakekatnya merupakan upaya melakukan peninjauan dan pendekatan kembali (re-orientasi dan reevaluasi) nilai-nilai sosiopolitik, sosiofilosofis dan sosiokultural yang melandasi dan memberi isi terhadap muatan normatif dan subtantif hukum pidana yang dicita-citakan. Bukan merupakan pembaharuan hukum pidana apabila orientasi nilai yang dicita-citakan sama saja dengan hukum pidana yang telah ada sebelumnya.

Dari penjelasan di atas dapat ditarik kesimpulan bahwa pembaharuan hukum pidana bukan hanya melakukan pembaharuan kebijakan dalam rangka mencapai kebijakan sosial, kebijakan kriminal, dan kebijakan penegakan hukum, namun lebih dari itu, pembaharuan hukum pidana harus berorientasi pada nilai-nilai yang dicita-citakan. Pembaharuan hukum pidana yang tanpa berorientasi pada nilai tidak akan menghasilkan produk yang bersifat jangka panjang.

\section{B. Sumbangan Pemikiran HAM terhadap Pembaharuan KUHAP}

Menurut Jan Materson, HAM merupakan hak-hak yang melekat pada manusia yang tanpanya manusia mustahil dapat hidup sebagai manusia. Menurut Burhanuddin Lopa, pada kalimat "mustahil dapat hidup sebagai manusia" hendaklah diartikan "mustahil dapat hidup sebagai manusia yang bertanggung jawab". Alasan ditambahkan kata "tanggung jawab" tersebut ialah disamping manusia memiliki hak, juga memiliki tanggung jawab atas segala 
yang dilakukannya. Sementara menurut John Lock, HAM adalah hak-hak yang diberikan langsung oleh Tuhan Yang Maha Pencipta (hak-hak yang bersifat kodrati) (Lopa, 1996: 1-2).

Konsepsi HAM sendiri memiliki dua dimensi (dimensi ganda) (Handoyo, 2003: 271). Pertama, dimensi universalitas, yakni substansi HAM itu pada hakekatnya bersifat umum dan tidak terikat oleh waktu dan tempat. HAM akan selalu dibutuhkan oleh siapa saja dan dalam aspek kebudayaan dimana pun itu berada, entah itu dalam kebudayaan barat maupun timur. Dengan kata lain hak asasi itu ada karena yang memiliki hak-hak itu adalah manusia sebagai manusia. Kedua, dimensi kontekstualitas, yakni menyangkut penerapan HAM bila ditinjau dari tempat berlakunya HAM tersebut. Maksudnya adalah ide-ide HAM dapat diterapkan secara efektif, sepanjang "tempat" ide-ide HAM itu memberikan suasana kondusif untuk itu.

Dalam lingkup Internasional, terdapat The International Bill of Human Rights yang merupakan istilah yang digunakan untuk acuan kolektif terhadap tiga instrumen pokok HAM dan protokol opsinya, yaitu (Rover, 2000: 55):

1. Pernyataan sejagat tentang Hak Asasi Manusia atau The Universal Declaration of Human Rights (UDHR) yang ditetapkan oleh PBB pada tanggal 10 Desember 1948.

2. Konvenan International tentang Hak-hak Sipil dan Politik atau International Convenant on Civil and Political Right (ICCPR).

3. Konvenan Internasional tentang Hak-Hak Ekonomi, Sosial dan Budaya atau International Convenant on Economic, Social, and Cultural Right (ICESCR).

4. Protokol Opsi Pertama pada ICCPR.

Pemikiran HAM banyak memberikan pengaruh terhadap warna hukum di Indonesia. Amandemen kedua UndangUndang Dasar 1945 telah memberikan perubahan terhadap pengaturan HAM di Indonesia. Jika sebelum amandemen kedua pengaturan HAM dalam Undang-Undang Dasar 1945 diatur secara terpisah pisah dalam beberapa pasal, namun pasca amandemen kedua, Undang-Undang Dasar 1945 telah mengatur HAM secara lebih sistematis dalam Bab XA. Disamping itu, perhatian Indonesia terhadap perlindungan HAM ditunjukkan dengan pengaturan HAM secara khusus melalui Undang-Undang Nomor: 39 Tahun 1999, tentang Hak Asasi Manusia.

Pemikiran HAM juga memberikan sumbangan terhadap ide pembaharuan KUHAP. Dalam konsideran Rancangan KUHAP disebutkan bahwa "pembaruan hukum acara pidana juga dimaksudkan untuk lebih memberikan kepastian hukum, penegakan hukum, ketertiban hukum, keadilan masyarakat, dan perlindungan hukum serta hak asasi manusia, baik bagi tersangka, terdakwa, saksi, maupun korban, demi terselenggaranya negara hukum." Dari konsideran tersebut terlihat bahwa salah satu nilai yang hendak dibangun dalam pembaharuan KUHAP adalah HAM.

Masuknya pemikiran-pemikiran HAM ke dalam pembaharuan KUHAP, tidak dapat dilepaskan dari pengaruh konvensi-konvensi internasional tentang HAM yang telah diratifikasi oleh Indonesia. Hal ini telah dinyatakan secara eksplisit dalam konsideran Rancangan KUHAP, yaitu "berhubung beberapa konvensi internasional yang berkaitan langsung dengan hukum acara pidana telah diratifikasi, maka hukum acara pidana perlu disesuaikan dengan materi konvensi tersebut."

\section{Sumbangan terhadap Perlindungan Hak-Hak Tersangka atau Terdakwa}

Ide perlindungan terhadap hak-hak tersangka atau terdakwa merupakan sumbangan dari pemikiran HAM yang terdapat dalam The International Bill of Human Rights, terutama UDHR dan ICCPR. UDHR banyak memberikan kontribusi yang signifikan terhadap konstitusi dan hukum nasional negara-negara anggota, tidak terkecuali Indonesia (Rover, 2000: 55). Sedangkan pembaharuan KUHAP lebih banyak dipengaruhi oleh ICCPR yang telah diratifikasi oleh Indonesia dengan Undang-Undang Nomor: 12 Tahun 2005.

ICCPR banyak memberikan sumbangan terhadap pembaharuan KUHAP terutama terkait dengan perlindungan hak tersangka atau terdakwa. Asas pokok yang menjadi payung perlindungan terhadap tersangka atau terdakwa adalah asas "praduga tidak bersalah." Asas praduga tidak bersalah merupakan asas yang menghendaki agar setiap orang yang terlibat dalam perkara pidana harus dianggap belum bersalah sebelum ada putusan pengadilan yang 


\section{MEDIA
HUKUM}

menyatakan kesalahan itu. Asas ini harus dipatuhi oleh penegak hukum baik dalam proses penyidikan, penuntutan maupun pemeriksaan di pengadilan (Muhammad, 2007: 17).

Pengaturan mengenai asas ini terdapat dalam Article 11 (1) UDHR yang menyatakan: "Everyone charged with a penal offence has the right to be presumed innocent until proved guilty according to law in a public trial at which he has had all the guarantees necessary for his defense." Senada dengan Article 11 UDHR, dalam Article 14 (2) ICCPR juga dinyatakan: "Everyone charged with a criminal offence shall have the right to be presumed innocent until proved guilty according to law."

Kedua Article tersebut memberikan hak kepada setiap orang untuk dianggap tidak bersalah sampai dibuktikan kesalahannya secara sah dalam suatu sidang pengadilan. Asas praduga tidak bersalah mengandung konsekuensi bahwa untuk dianggap bersalah oleh pengadilan, maka seseorang harus dipenuhi hak-haknya yang berupa: pertama, hak atas peradilan yang bebas, jujur dan tidak memihak (independent judiciary and fair trial). Kedua, hak atas bantuan dari profesi hukum yang bebas (independent legal profession). Dalam rangka menjamin agar proses peradilan tidak dilaksanakan secara sewenang-wenang, maka jalannya pemeriksaan harus terbuka untuk umum. Asas publisitas atau keterbukaan merupakan asas yang sangat pokok untuk menjamin berjalannya proses peradilan yang independen, jujur dan tidak memihak (Arief, 2008: 70-71).

Sebelum masuk ke dalam tahap pemeriksaan pengadilan, apabila seseorang ditangkap, maka ia berhak untuk segera diberitahukan mengenai tuduhan yang dikenakan kepadanya. Aticle 9 (2) ICCPR menyatakan bahwa "Anyone who is arrested shall be informed, at the time of arrest, of the reasons for his arrest and shall be promptly informed of any charges against him." Persoalan yang muncul terkait dengan pasal ini antara lain: Apakah informasi yang diberikan harus merupakan hal-hal yang umum atau yang khusus? dan apakah informasi harus disampaikan dalam bentuk tertentu? (Kasim, 2001: 184).

Untuk menjawab persoalan-persoalan tersebut, Komisi Eropa mengenai HAM memberikan petunjuk bahwa orang yang ditangkap atau ditahan cukup diberitahukan tuduhan yang bersifat umum saja, sedangkan pada saat diperiksa di pengadilan, informasi mengenai tuduhan terhadapnya diberitahukan secara resmi. Informasi mengenai tuduhan tersebut tidak harus tertulis dan jika diberikan secara lisan tidak perlu berbentuk khusus. Apabila orang yang ditangkap telah membaca surat perintah penangkapan, maka alasanalasan penangkapannya harus diberitahukan secara cepatcepat (Kasim, 2001: 184).

Hak selanjutnya adalah orang yang ditangkap atau ditahan berdasarkan tuduhan pidana wajib segera dihadapkan ke depan pengadilan atau pejabat lain yang diberi kewenangan oleh hukum untuk menjalankan kekuasaan peradilan, dan berhak untuk diadili dalam jangka waktu yang wajar, atau dibebaskan. Hak ini sebagaimana yang dijamin dalam Article 9 (3) ICCPR. Istilah "segera" di sini menunjukkan bahwa negara-negara harus memberikan batas waktu penahanan. Persoalannya setiap negara memiliki aturan yang berbeda mengenai batas waktu penahanan. Seringkali negara memberikan batas penahanan yang sangat panjang belum lagi masih ada perpanjangan dalam setiap habis masa penahanan. Inilah yang sering mengakibatkan pelanggaran terhadap ICCPR (Kasim, 2001: 185-186).

Dalam Article 9 (3) ICCPR juga disebutkan bahwa setiap orang berhak untuk diadili dalam jangka waktu yang wajar, atau dibebaskan. Maksud dari "waktu yang wajar" di sini berhubungan dengan Article 14 (3c) ICCPR, yaitu hak untuk diadili tanpa penundaan yang tidak semestinya. Untuk menilai sifat penundaan yang layak atau harus tidak dipandang in abstracto, melainkan dari sudut keadaankeadaan tertentu seperi kompleksitas kasusnya (Kasim, 2001: 192).

Setiap orang yang diperiksa berhak mendapatkan bantuan hukum sejak proses penyidikan hingga putusan pengadilan yang berkekuatan hukum tetap. Pemerintah menyediakan bantuan hukum kepada mereka yang tidak mampu untuk membiayainya. Untuk keadaan tertentu, tersangka atau terdakwa berhak mendapatkan bantuan lain terkait perlindungan haknya selama proses peradilan, misalnya untuk mendapatkan bimbingan rohani dan psikologi apabila diperlukan (Smith, et.al., 2008: 260-261).

Dalam rangka lebih memberikan jaminan terhadap hak tersangka atau terdakwa pada setiap proses peradilan, maka 
pada Rancangan KUHAP tetap dipertahankan beberapa prinsip di atas dan dilakukan pembaharuan dengan mengganti Praperadilan menjadi Hakim Komisaris. Hakim Komisaris akan menggantikan peranan Ketua Pengadilan Negeri (PN) atau Hakim Praperadilan. Dalam Pasal 1 angka 10 KUHAP dinyatakan bahwa Praperadilan hanya berwenang untuk memeriksa dan memutus tentang sah atau tidaknya suatu penangkapan dan/atau penahanan; sah atau tidaknya penghentian penyidikan atau penghentian penuntutan; dan permintaan ganti kerugian atau rehabilitasi oleh tersangka atau keluarganya atau pihak lain atas kuasanya yang perkaranya tidak diajukan ke pengadilan.

Meskipun memiliki wewenang yang terbatas, namun keberadaan Praperadilan dalam KUHAP merupakan ikon pembaruan terhadap HIR. HIR tidak mengatur bagaimana seseorang tersangka seharusnya dilindungi dari proses pemeriksaan penyidik ketika ditetapkan sebagai tersangka. Menurut HIR, penyidik harus dapat memperoleh pengakuan dari tersangka mengenai peristiwa yang melibatkan dirinya karena pengakuan tersangka merupakan salah satu alat bukti utama. Akibatnya, untuk memperoleh pengakuan tersangka, maka sering terjadi perlakuan yang sewenang-wenang dan penyalahgunaan wewenang oleh penyidik. Selain itu, HIR juga tidak memberikan perlindungan hukum yang memadai terhadap seorang tersangka tentang pemberian bantuan hukum yang hanya ditawarkan oleh penuntut umum terhadap seorang tersangka yang diancam dengan hukuman mati (Atmasasmita, 2010).

Keberadaan Praperadilan dalam perkembangannya kemudian memunculkan berbagai hambatan, sehingga maksud dan tujuan pemberlakuan Praperadilan tidak tercapai secara baik dan benar. Hal ini mengakibatkan hak-hak tersangka untuk memperoleh perlindungan hukum tidak terpenuhi dengan baik. Hambatan lain yang mencolok adalah bolak-baliknya perkara pidana dari penyidik POLRI ke Jaksa sehingga hak tersangka untuk memperoleh kepastian hukum terabaikan, bahkan sering terjadi bolakbaliknya perkara pidana dilatarbelakangi oleh kepentingan pribadi atau kelompok atau politik (Atmasasmita, 2010).

Beberapa kelemahan terhadap Praperadilan memunculkan ide untuk menggantinya dengan Hakim Komisaris. Dalam Pasal 111 ayat (1) Rancangan KUHAP, Hakim Komisaris diberikan wewenang yang jauh lebih luas dari Praperadilan, yaitu menetapkan atau memutuskan tentang:

1. Sah atau tidaknya penangkapan, penahanan, penggeledahan, penyitaan, atau penyadapan;

2. Pembatalan atau penangguhan penahanan;

3. Bahwa keterangan yang dibuat oleh tersangka atau terdakwa dengan melanggar hak untuk tidak memberatkan diri sendiri;

4. Alat bukti atau pernyataan yang diperoleh secara tidak sah tidak dapat dijadikan alat bukti;

5. Ganti kerugian dan/atau rehabilitasi untuk seseorang yang ditangkap atau ditahan secara tidak sah atau ganti kerugian untuk setiap hak milik yang disita secara tidak sah;

6. Tersangka atau terdakwa berhak untuk atau diharuskan untuk didampingi oleh pengacara;

7. Bahwa Penyidikan atau Penuntutan telah dilakukan untuk tujuan yang tidak sah;

8. Penghentian Penyidikan atau penghentian Penuntutan yang tidak berdasarkan asas oportunitas;

9. Layak atau tidaknya suatu perkara untuk dilakukan Penuntutan ke pengadilan; dan

10. Pelanggaran terhadap hak tersangka apapun yang lain yang terjadi selama tahap Penyidikan.

Keberadaan Hakim Komisaris dengan wewenang sebagaimana di sebutkan di atas lebih menunjukan jaminan perlindungan terhadap hak-hak tersangka dan terdakwa dibanding dengan Praperadilan. Pelanggaran HAM terhadap tersangka atau terdakwa tindak pidana bisa terjadi pada tataran norma (undang-undang), namun akan nampak lebih jelas dalam tataran penegakannya yang berupa pemeriksaan dalam semua tahapan sistem peradilan pidana. Dalam tahapan ini aparat penegak hukum berpotensi menggunakan kekuasaannya baik dalam bentuk ancaman fisik maupun psikis terhadap pelaku tindak pidana mulai dari pemanggilan, penentuan sebagai tersangka atau terdakwa, pemeriksaan yang berlarut-larut, penahanan yang tidak sah bahkan sampai pada rekayasa perkara. Rekayasa perkara merupakan pelanggaran HAM yang sangat kejam dalam proses penegakan hukum karena dengan sengaja menciptakan seseorang sebagai pelaku tindak pidana. Meminjam istilah Richard Quinney bahwa dengan rekayasa 
kasus berarti penegak hukum telah membangun rangkaian (proses) konstruksi kejahatan dalam proses peradilan (Muladi, 2007: 113).

Keberadaan Hakim Komisaris tersebut mengindikasikan bahwa model beracara dalam Rancangan KUHAP lebih condong kepada Due Process of Law (DPL). Sebagaimana ciri model DPL, keberadaan Hakim Komisaris menitikberatkan pada perlindungan hak-hak tersangka dan terdakwa dalam proses peradilan (Hiariej, 2010). Secara umum, DPL menekankan pada peran hukum dan aturan-aturan prosedural yang harus ditaati dalam setiap proses hukum. Prinsip pokok dari DPL antara lain: perlindungan tersangka atau terdakwa, persamaan para pihak, dan presumption of innocence (Setiawan, 2010: 10-11).

\section{Sumbangan terhadap Perlindungan Hak-Hak Korban}

Di samping perlindungan terhadap tersangka atau terdakwa, perkembangan pesat mengenai pemikiran HAM telah membawa pemikiran akan pentingnya perlindungan terhadap korban kejahatan. Dalam KUHAP, perlindungan terhadap korban masih sangat terbatas. Perlindungan korban dalam KUHAP hanya terdapat pada Pasal 98 ayat (1) yang berbunyi:

Jika suatu perbuatan yang menjadi dasar dakwaan di dalam suatu pemeriksaan perkara pidana oleh pengadilan negeri menimbulkan kerugian bagi orang lain, maka hakim ketua sidang atas permintaan orang itu dapat menetapkan untuk menggabungkan perkara gugatan ganti kerugian kepada perkara pidana itu.

Dalam penjelasan pasal tersebut, orang lain di sini termasuk korban, sehingga apabila korban merasa dirugikan terhadap seuatu kejahatan, ia dapat mengajukan gugatan ganti kerugian dengan menggabungkan dengan perkara pidana yang bersangkutan (Muhadar, et.al., 2009: 110). Ganti kerugian di sini bukan merupakan sanksi pidana, namun bersifat keperdataan karena dalam KUHP tidak dikenal sanksi pidana ganti kerugian, kecuali hanya sebagai syarat untuk seseorang tidak menjalani pidana bersyarat (Arief, 2007: 62).
Atas pengaruh perkembangan pemikiran HAM, maka memunculkan ide pembaharuan KUHAP yang menitikberatkan pada offender-victim protection oriented (perlindungan pelaku dan korban). Perhatian terhadap korban merupakan suatu keharusan atas dasar belas kasihan dan penghormatan terhadap martabatnya (compassion and respect for their dignity). Pada tahun 1985, PBB melalui Declaration of Basic Principle of Justice for Victims of Crime and Abuse of Power, memberikan perhatian yang lebih kepada akses korban untuk memperoleh keadilan, hak atas kompensasi, restitusi dan bantuan-bantuan lainnya yang harus diatur dalam Undang-Undang nasional. Bahkan kompensasi tersebut juga berlaku terhadap keluarganya, khususnya yang hidupnya tergantung pada korban yang mati atau cacat, termasuk di sini korban penyalahgunaan kekuasaan (Muladi, 2007: 106).

Dalam melakukan pengaturan terhadap perlindungan korban, aspek penting yang harus diperhatikan adalah esensi kerugian yang diderita oleh korban. Kerugian yang diderita korban dalam kejahatan bukan hanya bersifat materiel, namun lebih dari itu korban dapat menderita kerugian psikologis, seperti trauma kehilangan kepercayaan terhadap masyarakat dan ketertiban umum. Simtom dari sindrom tersebut dapat berupa kegelisahan, rasa curiga, sinisme, depresi, dan berbagai perilaku lainnya (Muladi dan Barda Nawawi, 2007: 64).

Pengaturan terhadap perlindungan korban dapat menggunakan model hak-hak prosedural (The Procedural Rights Model) dan model pelayanan (The Services Model). Model hak-hak prosedural memberikan kemungkinan kepada korban untuk dilibatkan dalam setiap tahapan proses peradilan. Dalam model ini, korban dapat diberikan hak untuk melakukan penuntutan pidana atau membantu kejaksaan untuk dihadirkan dalam setiap tingkat peradilan yang kepentingannya terkait, termasuk hak untuk mengadakan perdamaian. Sedangkan model pelayanan menekankan pada pemberian kompensasi sebagai sanksi pidana yang bersifat restitutif dan dampak-dampak pernyataan korban sebelum pidana dijatuhkan (Muladi dan Barda Nawawi, 2007: 85).

Menutut Stephen Schafer dalam Barda Nawawi Arief (1998: 59-61), terdapat lima sistem pemberian restitusi dan 
kompensasi terhadap korban kejahatan, yaitu:

1. Ganti kerugian bersifat keperdataan yang diberikan melalui proses perdata.

2. Kompensasi bersifat keperdataan yang diberikan melalui proses pidana.

3. Restitusi bersifat keperdataan dan bercampur dengan sifat pidana yang diberikan melalui proses pidana. Salah satu bentuk restitusi ini misalnya denda kompensasi (compensatory fine). Denda ini merupakan kewajiban yang dikenakan kepada terpidana sebagai suatu bentuk pemberian ganti kerugian kepada korban disamping pidana lain yang seharusnya dikenakan.

4. Kompensasi bersifat keperdataan yang diberikan melalui proses pidana dan disokong oleh negara. Kompensasi ini meskipun diberikan melalui proses pidana, namun tetap merupakan lembaga keperdataan murni tetapi negara yang menanggung ganti kerugian yang dibebankan kepada pelaku.

5. Kompensasi bersifat netral yang diberikan melalui prosedur khusus. Sistem ini diterapkan dalam hal korban memerlukan ganti kerugian namun pelaku tidak mampu membayar ganti kerugian tersebut.

Pemikiran-pemikiran HAM terhadap hak-hak korban telah memberikan sumbangan terhadap pembaharuan KUHAP. Dalam Rancangan KUHAP diatur hak-hak korban, baik melalui pelibatannya dalam proses peradilan maupun pemberian ganti kerugian kepada korban. Hak-hak korban yang terkait proses peradilan misalnya hak mengajukan laporan atau pengaduan kepada Penyidik baik secara lisan maupun secara tertulis (Pasal 12); hak atas pemberitahuan penghentian penyidikan (Pasal 14); dan hak memperoleh perlindungan hukum karena mengajukan laporan laporan atau pengaduan kepada Penyidik, serta perlindungan hukum dalam setiap proses Penuntutan dan proses pemeriksaan di sidang pengadilan (Pasal 40).

Sedangkan terkait ganti kerugian, pada bagian ketiga Rancangan KUHAP diatur mengenai Putusan Pengadilan tentang Ganti Kerugian Terhadap Korban. Pasal 135 ayat (1) dan (2) berbunyi:

(1) apabila terdakwa dijatuhi pidana dan terdapat korban yang menderita kerugian materiel akibat tindak pidana yang dilakukan oleh terdakwa, Hakim mengharuskan terpidana membayar ganti kerugian kepada korban yang besarnya ditentukan dalam putusannya.

(2) Apabila terpidana tidak membayar ganti kerugian sebagaimana dimaksud pada ayat (1), harta benda terpidana disita dan dilelang untuk membayar ganti kerugian kepada korban.

\section{SIMPULAN}

Tidak dapat dipungkiri bahwa ide pembaharuan KUHAP tidak terlepas dari sumbangan pemikiran HAM. Sumbangan ini secara eksplisit telah dicantumkan dalam konsiderans Rancangan KUHAP. Dari hasil kajian yang dilakukan, diperoleh kesimpulan bahwa sumbangan pemikiran HAM dalam pembaharuan KUHAP meliputi: Pertama, meskipun KUHAP sudah memberikan perlindungan terhadap hak-hak tersangka atau terdakwa, namun dalam implementasinya masih belum optimal. Oleh karena itu, dalam Rancangan KUHAP terdapat lembaga baru yang bernama Hakim Komisaris untuk menggantikan fungsi lembaga Praperadilan yang wewenangnya jauh lebih luas untuk lebih menjamin terpenuhinya hak-hak tersangka atau terdakwa dalam setiap tahapan proses peradilan.

Kedua, perkembangan pemikiran HAM memberikan sumbangan terhadap ide mengenai pengaturan hak-hak korban dalam pembaharuan KUHAP. KUHAP masih bersifat offender protection oriented, sehingga belum memberikan perlindungan hak-hak korban yang memadai. Karena belum diatur secara memadai, maka Rancangan KUHAP mengatur mengenai hak-hak korban, baik terkait dengan pelibatannya dalam setiap tahapan prosedur peradilan maupun hak untuk menuntut ganti kerugian. Pengaturan hak-hak korban dalam Rancangan KUHAP mencerminkan penekanannya terhadap offender-victim protection oriented.

\section{DAFTAR PUSTAKA}

Amrullah, Arief, 2007, Politik Hukum Pidana dalam Perlindungan Korban Kejahataan Ekonomi di Bidang Perbankan, Malang, Bayumedia Publishing,

Anwar, Yesmil dan Adang, 2008, Pembaruan Hukum Pidana; Reformasi Pidana, Jakarta, PT Gramedia Widia Sarana Indonesia.

Arief, Barda Nawawi, 2008, Bunga Rampai Kebijakan 
Hukum Pidana; Perkembangan Penyusunan Konsep KUHP Baru, Jakarta, Kencana Prenada Media Group. 2008, Kebijakan Hukum Pidana;

Perkembangan Penyusunan Konsep KUHP Baru, Jakarta, Kencana Prenada Media Group. , 2007, Masalah Penegakan Hukum dan

Kebijakan Hukum Pidana dalam Penanggulangan Kejahatan, Jakarta, Kencana Prebada Media Group. 2003, Kapita Selekta Hukum Pidana, Bandung, Citra Aditya Bakti. , 1998, Beberapa Aspek Kebijakan

Penegakan dan Pengembangan Hukum Pidana, Bandung, Citra Aditya Bakti.

Budiardjo, Mariam, 2008, Dasar-dasar Ilmu Politik, Jakarta, Penerbit Gramedia Pustaka Utama.

Dubber, Markus Dirk, 1999, "Reforming American Penal Law," Journal of Criminal Law and Criminology, Northwestern University School of Law, Tersedia di http://www.westlaw.com, Diakses tanggal 25 April 2011.

Handoyo, Restu Cipto, 2003, Hukum Tata Negara, Kewarganegaraan, dan Hak Asasi manusia, Yogyakarta, Universitas Atma Jaya.

Hiariej, Eddy O.S, "Asas Legalitas Dalam Hukum Acara Pidana," Makalah, Seminar Problem Dan Prospek RUU Hukum Acara Pidana Tim Pokja Nasional yang diselenggarakan Fakultas Hukum Universitas Gadjah Mada, Yogyakarta, Kamis 18 Maret 2010.

International Covenant on Civil and Political Rights, Adopted and opened for signature, ratification and accession by General Assembly resolution 2200A (XXI) of 16 December 1966.

Kasim, Ifdhal (editor), 2001, Hak Sipil dan Politik; EsaiEsai Pilihan, Jakarta, Lembaga Studi dan Advokasi Masyarakat (ELSAM).

Lopa, Burhanuddin, 1996, Al Qur'an dan Hak Asasi Manusia, Yogyakarta, PT Dana Bhakti Prima Yasa.

Moeljatno, 2008, Asas Asas Hukum Pidana, Jakarta, Penerbit Rineka Cipta.

Muhadar, dkk, 2009, Perlindungan Saksi dan Korban dalam Sistem Peradilan Pidana, Surabaya, CV. Putra Media Nusantara.

Muhammad, Rusli, 2007, Hukum Acara Pidana Kontemporer, Bandung, PT Citra Aditya Bakti.

Muladi (editor), 2007, Hak Asasi Manusia; Hakekat,
Konsep dan Implikasinya dalam Perspektif Hukum dan Masyarakat, Bandung, PT. Refika Aditama. dan Barda Nawawi, 2007, Bunga Rampai Hukum Pidana, Bandung, Alumni.

Najih, Mokhammad, 2008, Politik Hukum Pidana Pasca Reformasi, Malang, In-TRANS Publishing.

Prasetyo, Teguh, 2010, Kriminalisasi dalam Hukum Pidana, Bandung, Penerbit Nusa Media.

Romli Atmasasmita, "Analisis kritis atas RUU HAP 2009," Makalah, Seminar Problem dan Prospek RUU Hukum Acara Pidana Tim Pokja Nasional, Fakultas Hukum Universitas Gadjah Mada, Yogyakarta, Kamis, 18 Maret 2010.

Rover, C. De, 2000, To Serve $\mathcal{E}$ To Protect; Acuan Universal Penegakan HAM, Jakarta, PT. RajaGrafindo Persada.

Setiawan, Arif, 2010, "Pembaharuan Pra Peradilan (Studi tentang Pemaknaan Hukum oleh Polisi dalam Penyidikan," Ringkasan Disertasi, Program Doktor Ilmu Hukum, Universitas Diponegoro, Semarang. Smith, Rhona K.M, dkk, 2008, Hukum Hak Asasi Manusia, Yogyakarta, Pusat Studi Hak Asasi Manusia (PUSHAM) Universitas Islam Indonesia.

Suhelmi, Ahmad, 2001, Pemikiran Politik Barat: Kajian Sejarah Perkembangan Pemikiran Negara, Masyarakat dan Kekuasaan, Jakarta, Penerbit Gramedia Pustaka Utama.

Undang-Undang Republik Indonesia Nomor 39 tahun 1999 tentang Hak Asasi Manusia.

Universal Declaration of Human Rights, Adopted by the United Nations (UN) of 10 Desember 1948. 